\title{
Analysis of whale shark Rhincodon typus aggregations near South Ari Atoll, Maldives Archipelago
}

\author{
Morgan J. Riley*, Michelle S. Hale, Adam Harman, Richard G. Rees \\ School of Earth \& Environmental Sciences, University of Portsmouth, Burnaby Road, Portsmouth, PO1 3QL, UK
}

\begin{abstract}
We made surveys for whale sharks Rhincodon typus on a total of $99 \mathrm{~d}$ from April through June each year from 2006 to 2008 along the southern fringe of the South Ari Atoll, Maldives Archipelago. We recorded the length and sex of each shark observed and made photographs to facilitate repeated identification from their spot patterns using pattern-recognition software. We identified 64 whale sharks from digital photographs taken during 220 sightings over 3 yr. Approx. $87 \%$ of those sharks were immature males. The average length of recognisable sharks was $5.98 \mathrm{~m}$ (range 2.5 to $10.5 \mathrm{~m}$ ), significantly shorter than that reported for whale sharks in other aggregations in the Indian Ocean. Our findings suggest that these sharks are either a small proportion of a local population or perhaps an even smaller component of a regional population in the western Indian Ocean. We applied a Lincoln-Petersen closed-population mark-recapture model and a Jolly-Seber openpopulation model to estimate population size, but found that neither model provided reliable results because key assumptions of each were not met.
\end{abstract}

KEY WORDS: Whale shark - Rhincodon typus - Maldives Archipelago - Mark-recapture · Photo-identification

Resale or republication not permitted without written consent of the publisher

\section{INTRODUCTION}

Whale sharks Rhincodon typus are known to aggregate seasonally near shore and along coral reefs in tropical and subtropical waters worldwide (Stewart \& Wilson 2005). The timing of these aggregations often corresponds with local blooms of phytoplankton or spawning of fishes and corals (e.g. Clark \& Nelson 1997, Taylor \& Pearce 1999, Eckert \& Stewart 2001, Heyman et al. 2001, Alava et al. 2002, Norman \& Stevens 2007). Repeat observations of naturally marked or scarred whale sharks suggest that at least some sharks may be faithful to particular sites among years. Tracking studies and mtDNA data indicate, however, that whale sharks may be highly mobile between these visits (e.g. Eckert \& Stewart 2001, Eckert et al. 2002, Castro et al. 2007, Hsu et al. 2007, Rowat \& Gore 2007, Brunnschweiler et al. 2009), suggesting that multilateral regional cooperation and marine resource gover- nance may be the key to conservation of whale sharks (Castro et al. 2007).

Global abundance of whale sharks is unknown (Stewart \& Wilson 2005), although Castro et al. (2007) estimated that the effective female population size may be around 119000 to 238000 individuals. Local aggregations may have declined in some areas despite local protection (e.g. Theberge \& Dearden 2006, Bradshaw et al. 2008), suggesting unsustainable mortality in other parts of their range (Bradshaw et al. 2008) or perhaps only simple changes in distribution and patterns of movements. Holmberg et al. (2008) found no evidence of a decline in whale shark abundance at the same aggregation studied by Bradshaw et al. (2008), highlighting the difficulty in tracking population trends in an elusive species. Innate biological characteristics, such as large size, slow development and late maturation, delayed and infrequent reproduction and long life span, suggest the species cannot sustain high 
levels of exploitation. These factors, combined with the species' apparent widespread distribution, but disjunct and relatively small populations, mean that populations may be slow to recover from overexploitation (Jones \& Kaly 1995, Stewart \& Wilson 2005). Whale sharks have long been known to occur in Maldivian waters and indeed have been hunted historically (Anderson \& Ahmed 1993), although their abundance and population characteristics have not been studied before. Here we present preliminary information on whale sharks in the Maldives from our studies at South Ari Atoll from 2006 through 2008.

\section{MATERIALS AND METHODS}

We made surveys for whale sharks Rhincodon typus along the Maamigili-Dhigurah Reef $\left(03^{\circ} 28^{\prime} \mathrm{N}, 72^{\circ} 51^{\prime} \mathrm{E}\right)$ at South Ari Atoll on a total of $99 \mathrm{~d}$ from April through June each year from 2006 through 2008. The reef is located approximately $105 \mathrm{~km}$ southwest of the capital city of Malé in the Republic of Maldives (Fig. 1). We made surveys each day between 06:30 and 19:30 h from a $15.1 \mathrm{~m}$ long wooden-hulled, motorised boat. Our surveys coincided with the beginning of the southwest monsoon season.
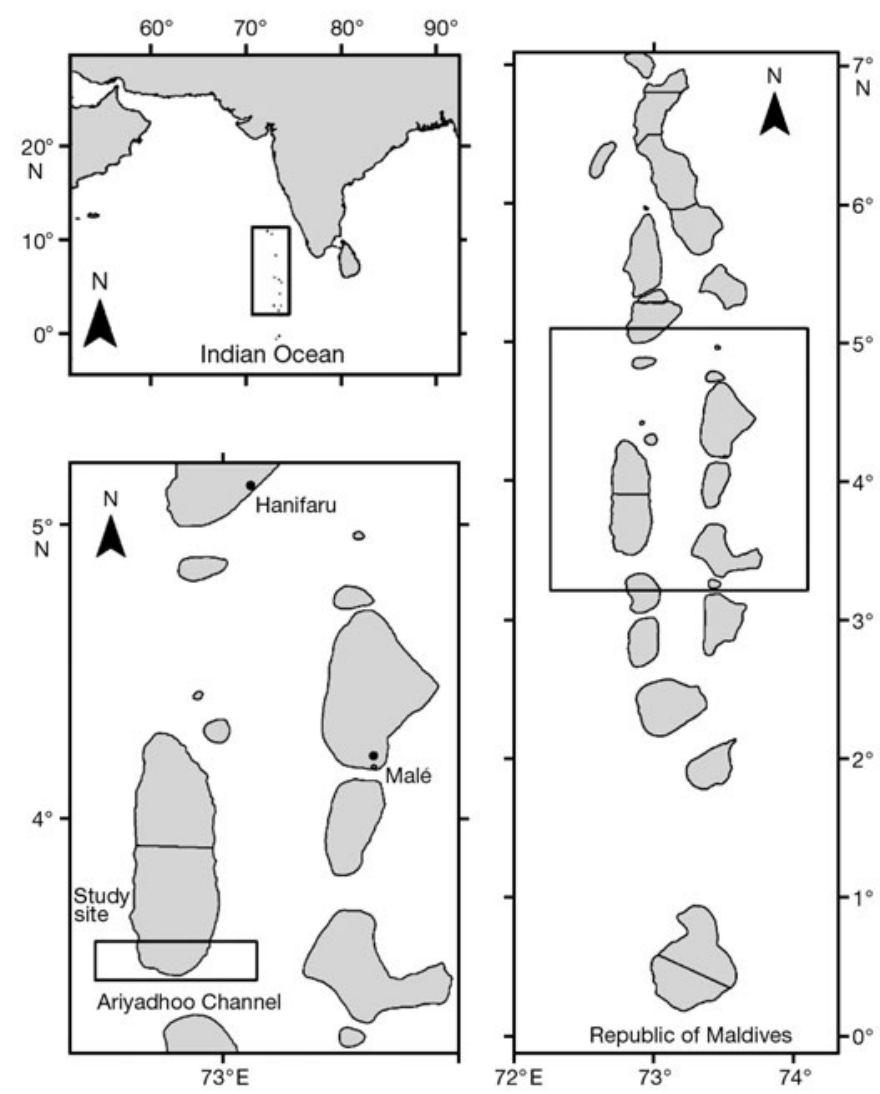

Fig. 1. Study site
Once a whale shark was sighted, the boat moved to just ahead of the animal and then dropped swimmers, with snorkels, into the water to take photographs, measure, and observe its behaviour. We measured total lengths $\left(L_{t}\right)$ of sharks either directly using a graduated measuring line, or by estimating it from photographs of a swimmer of known length next to it (e.g. Heyman et al. 2001, Norman \& Stevens 2007). We then calculated growth rates of identifiable sharks seen in 2006 and 2008 from differences in measured or estimated lengths.

We determined the sex of each shark by the observed presence (male) or absence (female) of mixopterygia (claspers) adjacent to the cloacal opening between the ventral pelvic fins (cf. Holden \& Raitt 1974). The claspers of immature male specimens are uncalcified and do not reach the posterior edge of the pelvic fin. In mature fish, the claspers extend beyond the posterior edge of the pelvic fin, and are hard and ossified (Holden \& Raitt 1974).

Keeping external tags attached to whale sharks has so far been difficult, and consequently a sample of marked animals for population assessment has not yet been established. However, whale sharks have striking body pigmentation patterns that may be suitable for identifying individual sharks (cf. Taylor 1994, Arzoumanian et al. 2005, Holmberg et al. 2008). To identify sharks, we made photographs of each shark we encountered and focused on the patterns of spots in an area defined by 4 boundaries: (1) just behind the 5th gill slit; (2) dorsal of the proximal end of the pectoral fin; (3) anterior of a line drawn dorso-ventrally from the insertion point of the posterior end of the pectoral fin; and (4) ventral of the 3rd longitudinal ridge (Arzoumanian et al. 2005) on both sides of each shark (Fig. 2). We used public-domain, pattern-recognition software ( $I^{3} S$, Interactive Individual Identification System) to evaluate matches among photographs (Van Tienhoven et al. 2007). Two or 3 observers made independent evaluations of photographs and results were compared to ascertain the accuracy of the algorithm determinations. We also used scar and wound patterns to verify the matches of some sharks. We included in our analyses only good quality photographs.

We applied a Lincoln-Petersen closed-population markrecapture model and a Jolly-Seber open-population model to the 3-yr dataset (e.g. Cormack 1964, Jolly 1965, Seber 1965) to estimate population size.

\section{RESULTS}

We recorded 220 sightings of whale sharks during $99 \mathrm{~d}$ of observations from 2006 through 2008. The frequency of encounters with whale sharks was $1.5 \mathrm{~d}^{-1}$ 


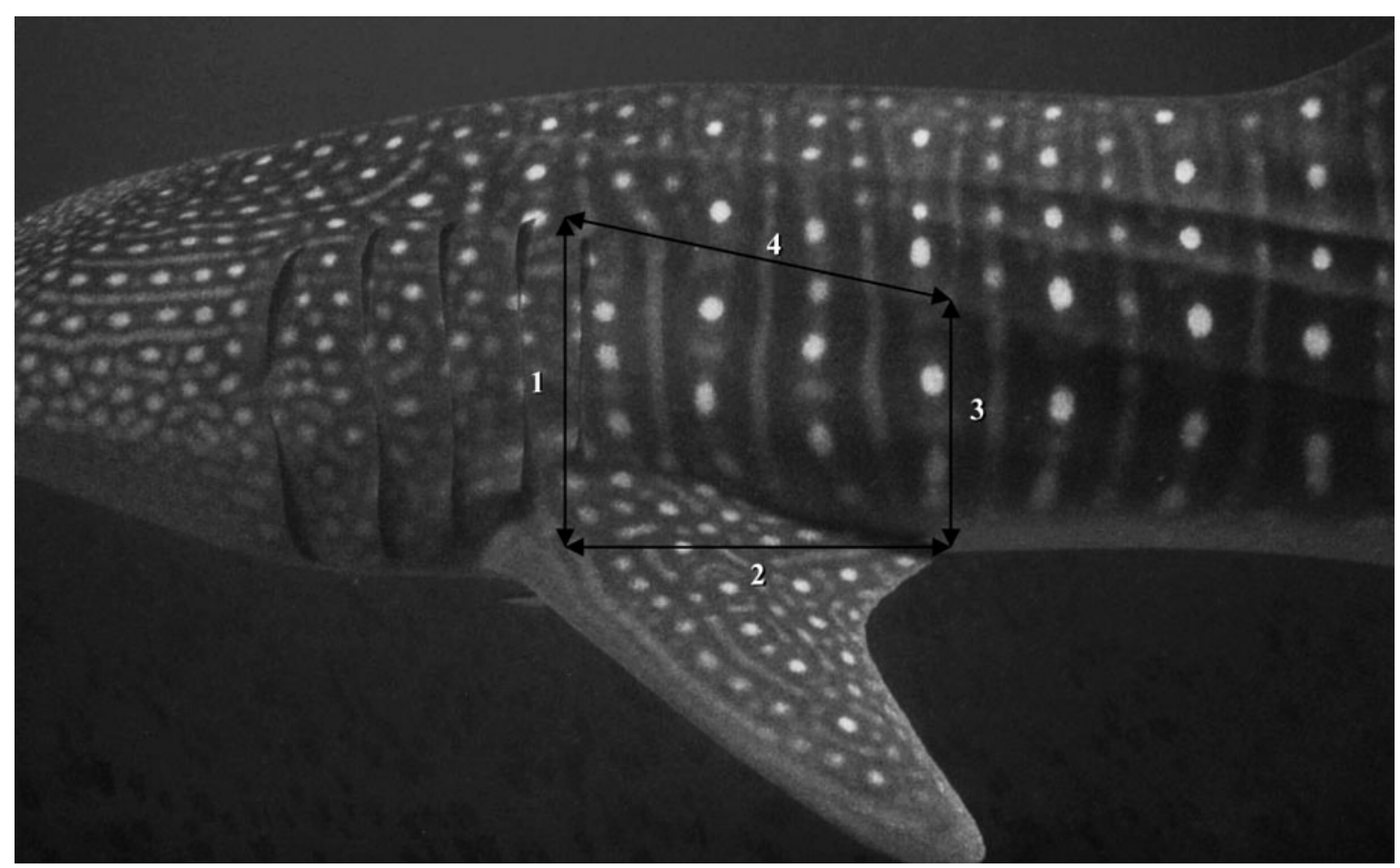

Fig. 2. Rhincodon typus. Identification area boundaries: (1) posterior of the 5th gill slit; (2) dorsal of the proximal end of the pectoral fin; (3) anterior of a line drawn dorsoventrally from the insertion point of the posterior end of the pectoral fin; and (4) ventral of the 3rd longitudinal ridge (Arzoumanian et al. 2005) on both sides of the shark

in 2006 and 2007 and $2.9 \mathrm{~d}^{-1}$ in 2008 (Table 1). We judged the photos made during 204 of the encounters with sharks to be of sufficient quality for comparing spot patterns. We identified 64 unique whale sharks from those photos, a minimum estimate of the number of whale sharks that have been foraging near the Maldives from 2006 to 2008 . Twelve $(35.3 \%)$ of them were observed in 2006 and 2007 and 20 (46.5\%) that were seen in 2008 had been observed in 2006 or 2007. Resightings varied among years. Eighteen sharks were seen between 4 and 8 times, one was seen 3 times, and 11 sharks were seen twice.

The Lincoln-Petersen closed-population model estimated population size to be between 62 and $99(95 \%$ CI). The Jolly-Seber open-population model in the programme MARK with the POPAN extension (White \&
Burnham 1999) estimated it at between 68 and 81 $(95 \% \mathrm{CI}, \mathrm{SE}=3.189)$.

The average length of whale sharks measured and estimated was $5.98 \mathrm{~m}\left(\mathrm{~L}_{\mathrm{t}} \pm 1.46 \mathrm{~m}\right.$, range 2.5 to $10.5 \mathrm{~m}$; $\mathrm{n}=64 ;$ Fig. 3). The smallest shark photographed was a $2.5 \mathrm{~m}$ male that we saw several times in 2008. We saw but did not photograph a slightly smaller shark $(<2.0 \mathrm{~m})$. The lengths of 13 resighted immature male sharks increased by about $0.45 \mathrm{~m} \mathrm{yr}^{-1}( \pm 0.37 \mathrm{~m})$ between 2006 and 2008.

Of 59 sharks whose sex was determined (Table 1), 56 $(95 \%)$ were immature males and the other 3 immature females (i.e. $<9 \mathrm{~m} \mathrm{~L}$ t; cf. Joung et al. 1996, Graham \& Roberts 2007). Of 5 sharks of unknown sex, one (WS037 at $10.5 \mathrm{~m}$ ) was the largest shark observed and was presumably mature (i.e. $>8.9 \mathrm{~m}_{\text {; }}$ cf. Norman \& Stevens 2007).

Table 1. Rhincodon typus. Number of whale sharks encountered, identified, measured and sexed, in 2006 (21 April to 16 May), 2007 (23 April to 10 June) and 2008 (24 April to 19 June). Total length $\left(\mathrm{L}_{t}\right)$ is the distance from tip of snout to tip of caudal fin. M: Male; F: female

\begin{tabular}{|c|c|c|c|c|c|c|c|c|c|c|c|}
\hline & \multirow[t]{2}{*}{ Encounters } & \multirow{2}{*}{$\begin{array}{l}\text { Search } \\
\text { (d) }\end{array}$} & \multirow{2}{*}{$\begin{array}{c}\text { Encounters } \\
\mathrm{d}^{-1} \text { search }\end{array}$} & \multirow{2}{*}{$\begin{array}{c}\text { Effort }(\mathrm{h}) \\
\text { per encounter }\end{array}$} & \multirow{2}{*}{$\begin{array}{c}\text { Total } \\
\text { sharks }\end{array}$} & \multicolumn{2}{|c|}{ Juveniles } & \multicolumn{2}{|c|}{ Mature } & \multirow[t]{2}{*}{ Unknown } & \multirow[t]{2}{*}{$\mathrm{L}_{\mathrm{t}}(\mathrm{m})$} \\
\hline & & & & & & $\mathrm{M}$ & $\mathrm{F}$ & M & $\mathrm{F}$ & & \\
\hline 2006 & 26 & 17 & 1.5 & 13.2 & 19 & 19 & 0 & 0 & 0 & 0 & $4.5-8.5$ \\
\hline 2007 & 63 & 42 & 1.5 & 9.6 & 34 & 32 & 0 & 0 & 0 & 2 & $4.0-10.5$ \\
\hline 2008 & 115 & 40 & 2.9 & 3.8 & 43 & 37 & 3 & 0 & 0 & 3 & $2.5-9$ \\
\hline All years & 204 & 99 & 2.1 & 6.8 & 64 & 56 & 3 & 0 & 0 & 5 & $2.5-10.5$ \\
\hline
\end{tabular}




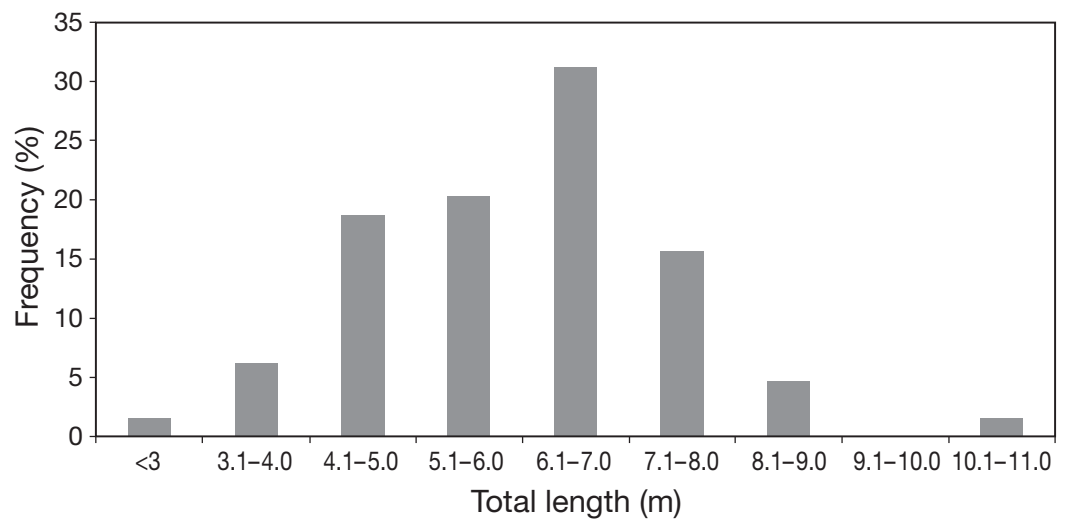

Fig. 3. Rhincodon typus. Size-frequency distributions of whale sharks photo-identified near South Ari Atoll, Maldives, 2006-2008 (n = 64)

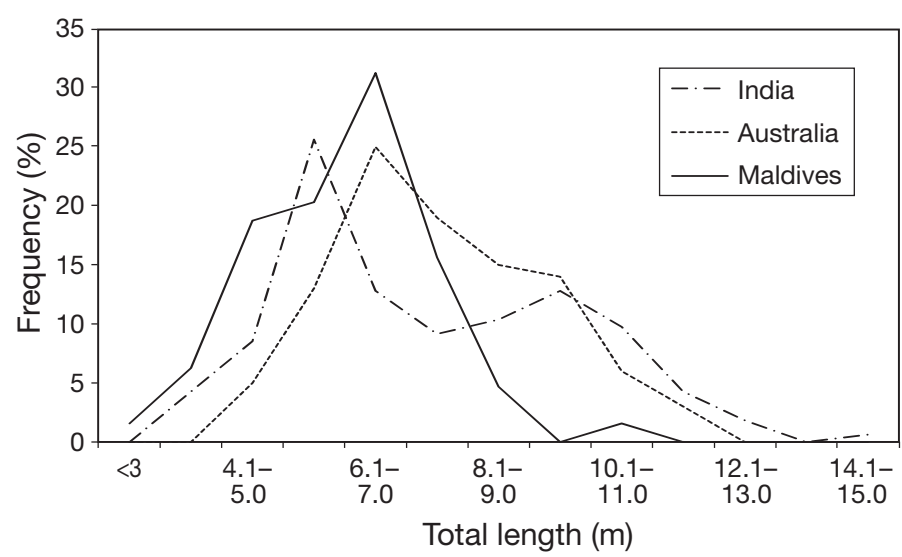

Fig. 4. Rhincodon typus. Size-frequency distributions of whale sharks (1) harvested in India, 1990-1998 ( $\mathrm{n}=164$ ) (Pravin 2000), (2) photographed at Ningaloo Reef, Western Australia, 1992-2004 ( $\mathrm{n}=84$ ) (Meekan et al. 2006), and (3) photographed at South Ari Atoll, Republic of Maldives, 2006-2008 $(n=64)$ (this study)

\section{DISCUSSION}

Resightings of whale sharks over 3 yr suggest that at least some sharks are faithful to the reef for short periods, at least in the boreal spring. Moreover, supplemental observations from another 103 encounters that identified 21 sharks in the Maldives (T. Davies pers. comm.), including regular resightings at the southern fringe of the South Ari Atoll during a 6-yr period, supports the hypothesis of local site fidelity of sharks during some period of their lives. Six of the sharks that were documented at the study site have also been observed about $190 \mathrm{~km}$ north at Hanifaru, Baa Atoll and 4 of those sharks were later seen again at the study site (Fig. 1). These observations suggest that a large number of the sharks that are observed in the Maldives may be year-round or perhaps permanent residents of the archipelago, at least until they mature.
The lengths $\left(5.98 \mathrm{~L}_{t} \pm 1.46 \mathrm{~m}\right)$ of whale sharks observed during this study were significantly less $(\mathrm{p}<0.001)$ than those harvested in India from 1990 to 1998 ( $\mathrm{n}=164,7.39 \pm$ $2.36 \mathrm{~m}$ ) and those photographed at Ningaloo Reef, Western Australia from 1992 to 2004 ( $\mathrm{n}=84,7.56 \mathrm{~L}_{\mathrm{t}} \pm 1.70 \mathrm{~m}$; Fig. 4). The estimated growth rate of $0.45 \mathrm{~m} \mathrm{yr}^{-1}( \pm 0.37 \mathrm{~m})$ for 13 individuals in the studied aggregation are similar to those of between 0.03 and $0.70 \mathrm{~m}$ $\mathrm{yr}^{-1}$ estimated for 3 immature whale sharks seen repeatedly during 2 to $3 \mathrm{yr}$ at Gladden Spit, Belize (Graham \& Roberts 2007). Immature whale sharks in aquaria initially between 4.5 and $4.9 \mathrm{~m} \mathrm{~L}_{\mathrm{t}}$ grew about 0.22 and $0.26 \mathrm{~m} \mathrm{yr}^{-1}$ over a 1.26 and 4 yr captive period respectively (Kitafuji \& Yamamoto 1998, Uchida et al. 2000). These similarities may suggest similar growth rates and age structure among areas, though extant data are not adequate to test either hypothesis.

Although more equal ratios of females to males have been reported for some aggregations of whale sharks (e.g. Theberge \& Dearden 2006, Cárdenas-Torres et al. 2007), most studies have reported greatly distorted sex ratios and size characteristics (e.g. Taylor 1994, Eckert \& Stewart 2001, Graham \& Roberts 2007, Norman \& Stevens 2007, Rowat \& Gore 2007, Rowat et al. 2008). Age or sexual segregation has been reported in basking sharks Cetorhinus maximus, another large planktivorous shark, and is widespread in Selachimorphs (e.g. Klimley 1987, Bres 1993, Robbins 2007). One reason for these distorted ratios and size characteristics of aggregations may be that only smaller sharks (and mostly males) approach the coasts and reefs close enough where they can be observed.

Discovery curves (number of individuals identified versus search effort) have been used in population studies of other marine vertebrates as an index of whether and when most individuals may have been seen (e.g. Kerr et al. 2005, Baker et al. 2006). Key assumptions of this model are that there is no uncatchable segment of the population (i.e. there are no whale sharks that are either never sighted or cannot be identified), and there are no additions to the population during the season that would cause true abundance to climb (Baker et al. 2006). The absence of newborn, mature adult and female sharks in general suggests that there is a large uncatchable segment of the population and there is no evidence to suggest that there are no additions to the population during the season. Consequently, we do not think that it is appropriate to derive discovery curves for this aggregation.

Mark-recapture methods can be used to estimate size and vital rates of populations even in highly mobile species (e.g. Cormack 1964, Jolly 1965, Seber 
1965, Pollock et al. 1990). They have been used to estimate abundances of whale sharks elsewhere in the Indian Ocean (Meekan et al. 2006, Rowat et al. 2009), although key assumptions may not have been satisfied.

We evaluated the applicability of mark-recapture methods, based on serial digital photographs of pigmentation patterns, to estimate abundance of whale sharks near South Ari Atoll. First we applied a simple LincolnPetersen mark-recapture model (closed-population assumed; Seber 1982). A critical assumption of this model is that there is no emigration or immigration (e.g. Kendall 1999). The absence of newborn and mature sharks and the predominance of immature males near South Ari Atoll suggests that the sharks that visit this location may indeed be only a small proportion of either a larger resident or regional population, indicating that emigration and immigration takes place. Consequently, a closed model is unlikely to be appropriate for estimating total population size and any output from one would be dubious.

We also used the Jolly-Seber (open-population) model in the Population Analysis (POPAN) option of MARK (White \& Burnham 1999) as has been used in previous whale shark studies (e.g. Meekan et al. 2006, Rowat et al. 2009). This model assumes that the population is open and that emigration and immigration both occur (Arnason \& Schwarz 1999). The Jolly-Seber openpopulation model assumes all individuals in the population have an equal probability of capture (Pledger et al. 2003), which for a transient marine species known to occupy a large geographic and vertical range (i.e. up to $1200 \mathrm{~m}$ or more in depth; Eckert \& Stewart 2001, Stewart \& Wilson 2005, Wilson et al. 2006, Wilson et al. 2007) is almost certainly false.

All mark-recapture models have key assumptions including that (1) with the exception of the LincolnPeterson model, each mark is unique to one individual (and the corollary that any change that might occur to a mark does not result in confusion with the mark of another individual), (2) there is no loss (or change) of the mark during the study (or at least that the rate of loss or change is small and can be accurately estimated), and (3) marks are accurately recorded and there is no (or minimal and measurable) error in recording when seen again. None of these assumptions have yet been tested for pigmentation patterns in whale sharks. Moreover, the use of mark-recapture models to estimate the size of episodic whale shark aggregations may be unreliable because the groups encountered may not represent functional breeding populations and consequently only an uncertain proportion of a larger regional or even wider-ranging population. Consequently, any reports of whale shark population size using mark-recapture models should be considered with these important caveats.
Provided the research is conducted within a sufficiently large area, open-population models may be useful over longer time periods to estimate abundance, survival and intraseasonal residency times (e.g. Holmberg et al. 2009). Therefore the continued collection of data on individual sharks using photo-identification may still represent the best method currently available for understanding the demography of aggregations of this species and to detect regional population trends. Further research to explore vertical and geographic movements of whale sharks in the Maldives is required to determined a scale appropriate for open-population models, to test the hypothesis that whale sharks segregate by size and sex and to determine the whereabouts and behaviour of the missing elements of the Indian Ocean whale shark population.

Acknowledgements. This research would not have been possible without the generous support of Conrad Rangali, Swallow Tree Gardens, the Royal Geographical Society, the Gilchrist Educational Trust, the Duke of Edinburgh's Trust No. 2 and the Earth and Space Foundation. The assistance of the Ministry of Fisheries, Agriculture and Marine Resources is gratefully acknowledged. The help of the dhoni captains and crew was essential, as was the support provided by the communities and resorts at the study site. The success of the research should be attributed to the Maldives Whale Shark Research Programme, and former team members J. Hancock, J. Leigh, R. Lloyd-Williams, A. Rees, and M. Tarrant. We thank 4 anonymous reviewers and Dr. B. Stewart for their suggestions for improving the manuscript.

\section{LITERATURE CITED}

Alava MNR, Dolumbalo ERZ, Yaptinchay AA, Trono RB (2002) Fishery and trade of whale sharks and manta rays in the Bohol Sea, Philippines. In: Fowler SL, Reed TM, Dipper FA (eds) Elasmobranch biodiversity, conservation and management: Proceedings of the international seminar and workshop. Shark specialist group, IUCN, Gland, p 132-148

Anderson RC, Ahmed H (1993) The shark fisheries in the Maldives. Food and Agriculture Organization of the United Nations, Rome and Ministry of Fisheries and Agriculture, Malé

> Arnason AN, Schwarz CJ (1999) Using POPAN-5 to analyse banding data. Bird Study 46(Suppl):S127-S168

- Arzoumanian Z, Holmberg J, Norman B (2005) An astronomical pattern matching algorithm for computer-aided identification of whale sharks Rhincodon typus. J Appl Ecol 42:999-1011

> Baker JD, Harting AL, Johanos TC (2006) Use of discovery curves to assess abundance of Hawaiian monk seals. Mar Mamm Sci 22:847-861

> Bradshaw CJA, Fitzpatrick BM, Steinberg CC, Brook BW, Meekan MG (2008) Decline in whale shark size and abundance at Ningaloo Reef over the past decade: the world's largest fish is getting smaller. Biol Conserv 141:1894-1905

- Bres M (1993) The behaviour of sharks. Rev Fish Biol Fish 3:133-159

> Brunnschweiler J, Baensch H, Pierce S, Sims D (2009) Deepdiving behaviour of a whale shark Rhincodon typus dur- 
ing long-distance movement in the western Indian Ocean. J Fish Biol 74:706-714

Cárdenas-Torres N, Enríquez-Andrade R, Rodríguez-Dowdell N (2007) Community-based management through ecotourism in Bahia de los Angeles, Mexico. Fish Res 84: $114-118$

> Castro ALF, Stewart BS, Wilson SG, Hueter RE and others (2007) Population genetic structure of Earth's largest fish, the whale shark (Rhincodon typus). Mol Ecol 16: 5183-5192

- Clark E, Nelson DR (1997) Young whale sharks, Rhincodon typus, feeding on a copepod bloom near La Paz, Mexico. Environ Biol Fishes 50:63-73

Cormack RM (1964) Estimates of survival from the sighting of marked animals. Biometrika 51:429-438

- Eckert SA, Stewart BS (2001) Telemetry and satellite tracking of whale sharks, Rhincodon typus, in the Sea of Cortez, Mexico, and the North Pacific Ocean. Environ Biol Fishes 60:299-308

> Eckert SA, Dolar LL, Kooyman GL, Perrin W, Rahman A (2002) Movements of whale sharks (Rhincodon typus) in South-east Asian waters as determined by satellite telemetry. J Zool (Lond) 257:111-115

> Graham R, Roberts C (2007) Assessing the size, growth rate and structure of a seasonal population of whale sharks (Rhincodon typus Smith 1828) using conventional tagging and photo identification. Fish Res 84:71-80

Heyman WD, Graham RT, Kjerfve B, Johannes RE (2001) Whale sharks Rhincodon typus aggregate to feed on fish spawn in Belize. Mar Ecol Prog Ser 215:275-282

Holden MJ, Raitt DFS (1974) Manual of fisheries science part 2: methods of resource investigation and their application. FAO Fisheries Technical Paper 115, rev. 1, United Nations, Rome

- Holmberg J, Norman B, Arzoumanian Z (2008) Robust, comparable population metrics through collaborative photomonitoring of whale sharks Rhincodon typus. Ecol Appl $18: 222-233$

Holmberg J, Norman B, Arzoumanian Z (2009) Estimating population size, structure, and residency time for whale sharks Rhincodon typus through collaborative photoidentification. Endang Species Res 7:39-53

Hsu HH, Joung SJ, Liao YY, Liu KM (2007) Satellite tracking of juvenile whale sharks, Rhincodon typus, in the Northwestern Pacific. Fish Res 84:25-31

Jolly GM (1965) Explicit estimates from capture-recapture data with both death and immigration-stochastic model. Biometrika 52:225-247

Jones GP, Kaly UL (1995) Conservation of rare, threatened and endemic marine species in Australia. The state of the marine environment for Australia, Technical Annex: 1. The marine environment. In: Zann LP, Kailola P (eds) Ocean rescue 2000. Department of the Environment, Sports and Territories, Canberra, p 183-191

Joung SJ, Chen CT, Clark E, Uchida S, Huang WYP (1996) The whale shark, Rhincodon typus, is a livebearer: 300 embryos found in one 'megamamma' supreme. Environ Biol Fishes 46:219-223

Kendall WL (1999) Robustness of closed capture-recapture methods to violations of the closure assumption. Ecology 80:2517-2525

Kerr K, Defran RH, Campbell GS (2005) Bottlenose dolphins (Tursiops truncatus) in the Drowned Cayes, Belize: group size, site fidelity and abundance. Caribb J Sci 41:172-177

Kitafuji M, Yamamoto K (1998) Rearing of the whale shark, Rhincodon typus, in the Osaka aquarium 'Kaiyukan'. J Jpn Assoc Zool Aquat 39:47-54

Klimley A (1987) The determinants of sexual segregation in

Editorial responsibility: Brent Stewart,

San Diego, California, USA the scalloped hammerhead shark, Sphyrna lewini. Environ Biol Fishes 18:27-40

Meekan MG, Bradshaw CJA, Press M, McLean C, Richards A, Quasnichka S, Taylor JG (2006) Population size and structure of whale sharks Rhincodon typus at Ningaloo Reef, Western Australia. Mar Ecol Prog Ser 319:275-285

Norman BM, Stevens JD (2007) Size and maturity status of the whale shark (Rhincodon typus) at Ningaloo Reef in Western Australia. Fish Res 84:81-86

> Pledger S, Pollock KH, Norris JL (2003) Open capture-recapture models with heterogeneity. I. Cormack-Jolly-Seber model. Biometrics 59:786-794

Pollock KH, Nichols JD, Brownie C, Hines JE (1990) Statistical inference for capture-recapture experiments. Wildl Monogr 107:1-97

Pravin P (2000) Whale shark in the Indian coast-need for conservation. Curr Sci 79:310-315

Robbins R (2007) Environmental variables affecting the sexual segregation of great white sharks Carcharodon carcharias at the Neptune Islands South Australia. J Fish Biol 70: $1350-1364$

> Rowat D, Gore M (2007) Regional scale horizontal and local scale vertical movements of whale sharks in the Indian Ocean off Seychelles. Fish Res 84:32-40

Rowat D, Gore MA, Baloch BB, Islam Z and others (2008) New records of neonatal and juvenile whale sharks (Rhincodon typus) from the Indian Ocean. Environ Biol Fishes 82: 215-219

Rowat D, Speed CW, Meekan MG, Gore MA, Bradshaw CJA (2009) Population abundance and apparent survival of the vulnerable whale shark Rhincodon typus in the Seychelles aggregation. Oryx 43:591-598

> Seber GAF (1965) A note on the multiple-recapture census. Biometrika 52:249-259

Seber GAF (1982) The estimation of animal abundance and related parameters, 2nd edn. Hafner, New York

> Stewart BS, Wilson SG (2005) Threatened fishes of the world: Rhincodon typus (Smith 1828) (Rhincodontidae). Environ Biol Fishes 74:184-185

Taylor JG (1994) Whale sharks: the giants of Ningaloo Reef. Angus \& Robertson, Sydney

Taylor JG, Pearce AF (1999) Ningaloo Reef currents: implications for coral spawn dispersal, zooplankton and whale shark abundance. J R Soc West Aust 82:57-65

- Theberge MM, Dearden P (2006) Detecting a decline in whale shark Rhincodon typus sightings in the Andaman Sea, Thailand, using ecotourist operator-collected data. Oryx 40:337-342

Uchida S, Toda M, Kamei Y, Teruya H (2000) The husbandry of 16 whale sharks Rhincodon typus, from 1980 to 1998 at the Okinawa expo aquarium. In: Abstracts of the American Elasmobranch Society, 16th Annual Meeting. La Paz, Mexico, p 359

> Van Tienhoven AM, Den Hartog JE, Reijns R, Peddemors VM (2007) A computer-aided program for pattern-matching of natural marks of the spotted raggedtooth shark Carcharias taurus (Rafinesque,1810). J Appl Ecol 44:273-280

- White GC, Burnham KP (1999) Program MARK: survival estimation from populations of marked animals. Bird Study 46:120-138

Wilson S, Polovina JJ, Stewart BS, Meekan MG (2006) Movements of whale sharks (Rhincodon typus) tagged at Ningaloo reef, Western Australia. Mar Biol 148:1157-1166

Wilson SG, Stewart BS, Polovina JJ, Meekan MG, Stevens JD, Galuard B (2007) Accuracy and precision of archival tag data: a multiple-tagging study conducted on a whale shark (Rhincodon typus) in the Indian Ocean. Fish Oceanogr 16:547-554

Submitted: December 23, 2008; Accepted: November 23, 2009 Proofs received from author(s): January 11, 2010 